\title{
The Palimpsest Catena of Codex Zacynthius: Text and Translation
}

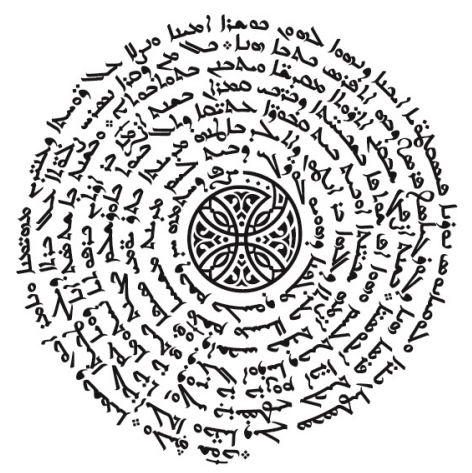




\section{Texts and Studies \\ (Third Series)}

\section{Series Editor}

\section{H. A. G. Houghton}

Editorial Board

Jeff W. Childers

Alba Fedeli

Viktor Golinets

\section{Christina M. Kreinecker}

Gregory S. Paulson

Peter J. Williams

Texts and Studies is a series of monographs devoted to the study of Biblical and Patristic texts. Maintaining the highest scholarly standards, the series includes critical editions, studies of primary sources, and analyses of textual traditions. 
The Palimpsest Catena of Codex Zacynthius: Text and Translation

\author{
By \\ H. A. G. Houghton \\ Panagiotis Manafis
}

A. C. Myshrall

Gorgias

2020 
Gorgias Press LLC, 954 River Road, Piscataway, NJ, 08854, USA

www.gorgiaspress.com

Copyright (C) 2020 by Gorgias Press LLC

All rights reserved under International and Pan-American Copyright Conventions. No part of this publication may be reproduced, stored in a retrieval system or transmitted in any form or by any means, electronic, mechanical, photocopying, recording, scanning or otherwise without the prior written permission of Gorgias Press LLC.

This book is published in Open Access under a Creative Commons 4.0 License BY-NC-ND

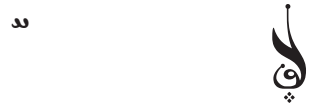

ISBN 978-1-4632-4105-6

ISSN 1935-6927

Library of Congress Cataloging-in-Publication Data

A Cataloging-in-Publication Record is available at the Library of Congress.

Printed in the United States of America 
The material on which this edition is based was created by the Codex Zacynthius Project, supported by the Arts and Humanities Research Council.

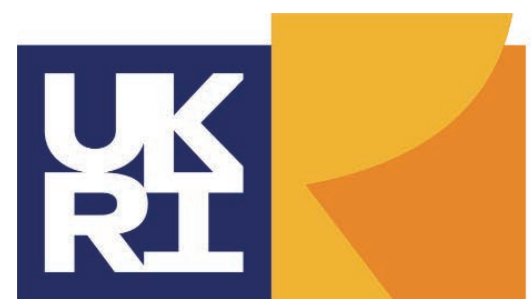

\section{Arts and Humanities Research Council}

The preparation of this edition and its publication in Open Access was undertaken as part of the CATENA project, which has received funding from the European Research Council (ERC) under the European Union's Horizon 2020 research and innovation programme (grant agreement no. 770816).
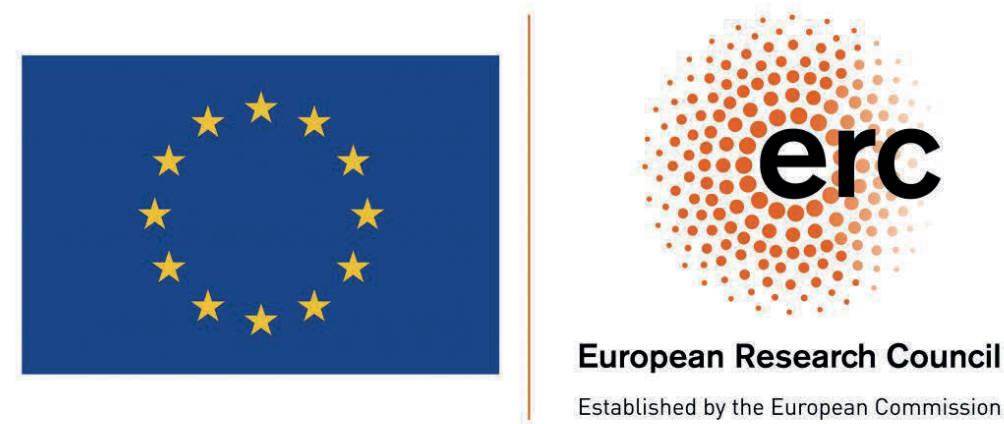
